\title{
Repellent Activity of Piper spp. Leaves Extracts on Rice Ear Bugs (Leptocorisa oratorius Fabricius) and the Characters of Its Volatile Compounds
}

\author{
Laurentius Hartanto Nugroho ${ }^{1}$, Rarastoety Pratiwi ${ }^{1}$, R. C. Hidayat Soesilohadi ${ }^{1}$, \\ Efrida Ratnasari Subin ${ }^{1}$, Sri Wahyuni ${ }^{1}$, Jekli ${ }^{1}$, Yustina Sri Hartini ${ }^{2}$ \\ and Intani Quarta Lailaty ${ }^{1,3^{*}}$
}

${ }^{1}$ Faculty of Biology, Universitas Gadjah Mada, Yogyakarta, Indonesia. Jln. Teknika Selatan, Sekip Utara, Yogyakarta, Indonesia.

${ }^{2}$ Faculty of Pharmacy, Sanata Dharma University, Yogyakarta, Paingan Maguwoharjo Depok Sleman Yogyakarta, Indonesia.

${ }^{3}$ Research Center for Plant Conservation and Botanic Gardens, Indonesian Institute of Sciences,

Bogor, West Java, Indonesia.

\section{Authors' contributions}

This work was carried out in collaboration among all authors. Author LHN designed the study, performed the statistical analysis, wrote the protocol and wrote the first draft of the manuscript. Authors RP and RCHS managed the analyses of the study. Author RCHS managed the literature searches. Authors ERS and SW developed modified olfactometer. Author Jekli identified Piper spp.

Authors YSH and IQL applied and analysed GC-MS. All authors read and approved the final manuscript.

\section{Article Information}

DOI: $10.9734 / A R R B / 2020 / v 35 i 930000$

Editor(s):

(1) Dr. Saleha Sadeeqa, Lahore College for Women University, Pakistan. Reviewers:

(1) Adewole Adekanmi, Federal Polytechnic llaro, Nigeria.

(2) Heba Youssif El-Sayed Ibrahim, Plant Protection Research Institute and Agricultural Research Center (ARC), Egypt. Complete Peer review History: http://www.sdiarticle4.com/review-history/60165

Original Research Article

Received 06 June 2020

Accepted 12 August 2020

Published 31 August 2020

\begin{abstract}
Rice ear bug (Leptocorisa oratorius Fabricius) is still classified as the top of five pests that cause the most losses in rice farming productivity. The attack causes the grain to become empty resulted in reducing the yield of grain up to $40 \%$ even to $100 \%$. Betel plants (Genus Piper) are easy to grow and grown by almost all households in Indonesia. Ethnobotany showed that betel is used as one of the insect controllers. This research aimed to study the repellant activities of five species of Piper
\end{abstract}


spp. and their phytochemical composition based on CG-MS chromatograms. Moreover, the active compounds were analyzed in potent plant. The repellant activities of chloroform and methanol extract of $P$. betle, $P$. aduncum, $P$. nigrum, $P$. longum, and $P$. crocatum were applied using modified olfactometer, while the phytochemical composition were analyzed using GC-MS. The compounds with insecticidal activity in the potent species were analyzed by the references. The results showed that chloroform extract of $P$. crocatum was the most potent extract. It contains 28 specific compounds which were not found in other species. Literature studies showed that compounds that had repellent activities are monoterpene and sesquiterpene groups.

Keywords: Rice ear bug; repellent; Piper spp.; volatile compounds; biopesticide.

\section{INTRODUCTION}

Rice ear bug (Leptocorisa oratorius Fabricius) of the family, Alydidae order Hemiptera, is a pest, either as adult insect or nymph, which can attack the grain of the flowering phase until the ripe milk. It is very dominant in lowland rice fields [1]. This pest caused $5.59 \%-14.23 \%$ damage to rice in the reproductive phase (ripe milk) in the paddy fields of the Dusun Besar Village of Bengkulu, Indonesia [2]. In Maluku Province of Indonesia, the damage occurred by $22.95 \%$ due to rice ear bug and $3.30 \%$ caused by white rice borer [3].

Various methods of pest control, such as biological, mechanical and chemical have can be used in controlling the pest. Pest control using chemical synthetic pesticides is still the main choice even though it has been known to have a serious impact on ecosystems and may be toxic to animals, humans and non-target organisms. Excessive use of synthetic pesticides also causes pest resistance to various pesticides [4]. As an alternative, currently there are many integrated pest control efforts with Integrated Pest Management (IPM) which include the development of pest-resistant varieties, and the development of biopesticides or vegetable pesticides. Biopesticides have been developed as insecticides which are directed to the discovery of compounds that are not only effective in pest control but also have selective activities against certain insect pests. Rational control agents can change insect growth regulators and change the behavior of insects, such as pheromones and allelochemistry [5].

Vegetable pesticides come from plant parts such as roots, tubers, leaves, skin, stems, fruit and seeds. The ingredients are processed into various forms, including flour, extract or resin which is the secondary result of metabolite fluids from plant parts as insecticides [6]. Environmental pest controls have been carried out by several researchers using Piper plant extracts. In a research conducted by Yunianti [7], the application of a green betel (Piper betle) leaves water extract with a concentration of $75 \%$ can kill pests of stinky rice pest as much as $60 \%$. Jayalakshmi et al. [8] reported that the methanol leaves extract of $P$. betle contain of flavonoids, tannins, steroids, glycosides, proteins and carbohydrates, while chloroform leaves extracts of $P$. betle contained alkaloids, glycosides and proteins.

Leaves extracts compounds of other members of the genus Piper are also identified. The methanol leaves extract of red betel (Piper crocatum) was conducted by Lister et al. [9], the results showed that the leaf extract of the plant contain of alkaloids, flavonoids (flavonols, flavansons, isoflavones, aurons, cathechins, antocyanidines, chalcones), saponins, triterpenoids, and tannins. In current research, therefore, the repellent activity of Piper spp. leaves extracts and its secondary metabolite compositions were analyzed and detected.

\section{MATERIALS AND METHODS}

\subsection{Sample Preparation}

The five species of Piper: Piper betle, $P$. aduncum, $P$. nigrum, $P$. longum, and $P$. crocatum, were identified in the laboratory of Plant Systematic, Faculty of Biology, Universitas Gadjah Mada, Yogyakarta, Indonesia. The specimens and leaves samples were stored at the Laboratory of Plant Structure and Development, Faculty of Biology, Universitas Gadjah Mada, Yogyakarta, Indonesia.

Preparation of five Piper spp. leaves extract using the maceration method with chloroform and methanol solvent. The leaves were cleaned of dirt, dried under the sunlight while covered by black cloth, then dried in an oven at $40{ }^{\circ} \mathrm{C}$ and mashed into powder. Five grams of the powder was put into an Erlenmeyer flask, soaked using $150 \mathrm{ml}$ of chloroform and covered with aluminum foil for 24 hours while occasionally shaken. After 
24 hours the pulp was separated from the filtrate by filter paper. The chloroform filtrate was placed on a porcelain cup and concentrated with a fan. The pulp which has been separated from the filtrate was dried in an oven at $40^{\circ} \mathrm{C}$ and after drying the pulp was macerated for 24 hours using a second solvent, $150 \mathrm{ml}$ of methanol. After 24 hours, methanol filtrate was separated from the pulp by filter paper, then concentrated with a fan. Next, the chloroform and methanol extract from Piper spp. were stored in a cold room for further test.

\subsection{Repellent Activity Test}

Piper spp. leaves extracts were tested for their repellant activity to rice ear bug using modified olfactometer from Netto [10] with three different concentrations. Each kind of Piper spp. leaves extracts were diluted using water added with DMSO to $25 \%, 37.5 \%$ and $50 \%$ of extracts concentrations [11,7].

Repellant test was done by placing one pot of rice mature milk in each arm of the olfactometer $(35 \mathrm{~cm} \times 35 \mathrm{~cm} \times 75 \mathrm{~cm})$. The extract solution was sprayed on the treatment of rice plants for bioassays. Each test unit was used as many as 10 rice ear bugs that have been acclimatized for 24 hours, then were released into the olfactometer body. Observations were carried out for 24 to 36 hours. The behavior of the rice ear bug observed was the preference of the bug to choose either rice plants that treated with Piper spp. leaves extract treatment or control. The treatments were carried out with 3 replications.

\subsection{Identification of Chemical Compounds}

The chemical compounds of Piper spp. chloroform leaves extracts were analyzed by GCMS (Agilent GC 6890N 5975B MSD). The capillary column was Agilent 19091S-433 model, HP-5MS 5\% Phenyl Methyl Siloxane. The oven temperature was programmed as follows: initial temperature at $100^{\circ} \mathrm{C}$, initial time for 1.00 minute, final temperature at $300^{\circ} \mathrm{C}$ for 10.0 minute. Identification of components in sample used Wiley7Nist05.L data based.

\subsection{Data Analysis}

Determination the repellency of chloroform leaves extract of Piper spp. which has the highest repellent by calculating the value of Inhibition Concentration (IC) using probit analysis [12]. To calculate the IC value required percent inhibition data from the tests conducted. Percent inhibition can be calculated using the formula Gour and Tembhre [13] as follows:

$$
\% \text { inhibiton }=\frac{\begin{array}{c}
\text { Control inhibition - } \\
\text { treatments }
\end{array}}{\text { Control inhibition }} \times 100 \%
$$

Chromatograms of Piper spp. leaves extract were compared based on the kind of components and the concentration of each component. Data were correlated with the results of repellant activity test. The characteristic compounds (resulted from GC-MS chromatograms) in the potent sample were predicted as the potent compounds.

\section{RESULTS AND DISCUSSION}

\subsection{Modified Olfactometer}

In this study, the olfactometer was used based on Netto's research [10] as shown in Fig. 1. The use of Netto's olfactometer design failed due to no movement of rice ear bugs into a box filled with ripe rice milk when optimizing olfactometer was done. Therefore, the olfactometer design was modified by removing the rice bug storage box, the connecting hose between the rice bug storage box and the milk-cooked rice box, and the glass cover. In new modified olfactometer design, the glass cover was replaced with a cardboard with a hole in the bottom so that the movement space was more widespread, the side of the cardboard was affixed with transparent plastic, so that light can enter the cardboard, as shown in Fig. 2 and Fig. 3. The olfactometer design as the results of the modification were further used in the repellent test because at the time of the optimization, it was shown that rice ear bugs were able to move freely and alighted on the mature rice milk plant.

\subsection{Repellent Activity}

Determination of the most potential extracts to drive out rice ear bug using probit analysis was seen from the $\mathrm{IC}_{50}$ value. Based on the probit analysis, it was found that the $\mathrm{IC}_{50}$ values of the $P$. crocatum chloroform extract and methanol extract were $3.71 \%$ and $19.61 \%$, while those of the chloroform and methanol extract of $P$. betle was 24.99 (Fig. 4). It was known that the Piper extract which has the most potential to drive out rice ear bugs was the chloroform and methanol extract of $P$. crocatum. Next, the chloroform extract of $P$. crocatum was used in analyzes of phytochemical composition based on CG-MS chromatograms. 


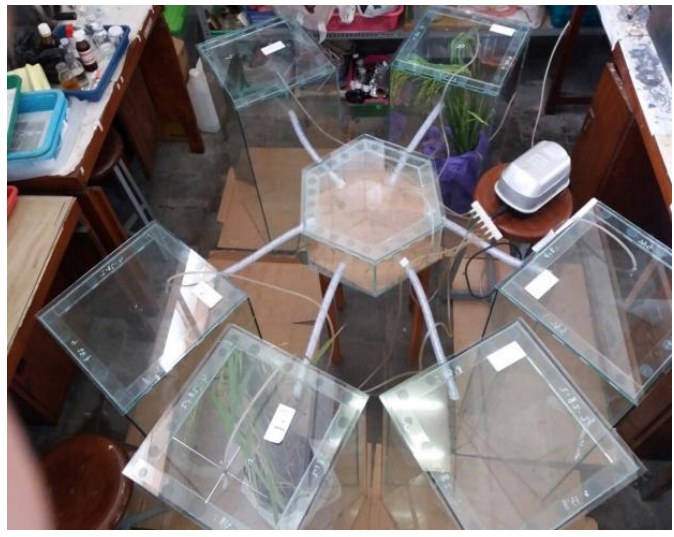

Fig. 1. First modified olfactometer

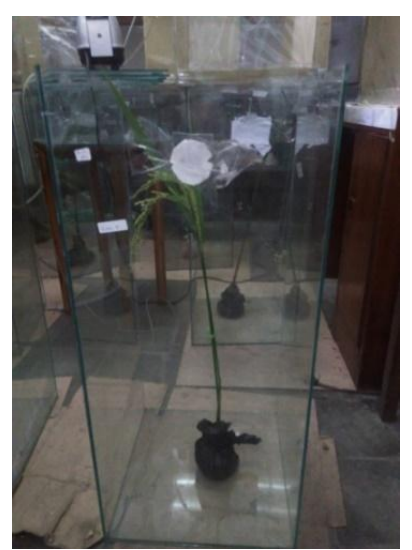

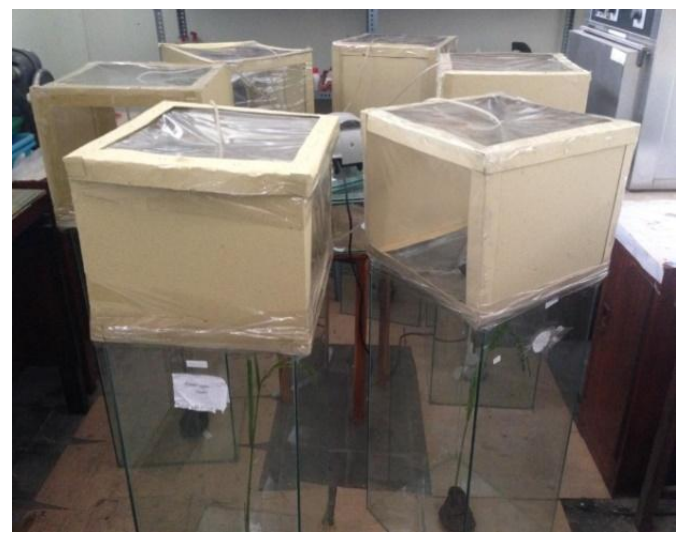

Fig. 2. Second modified olfactometer
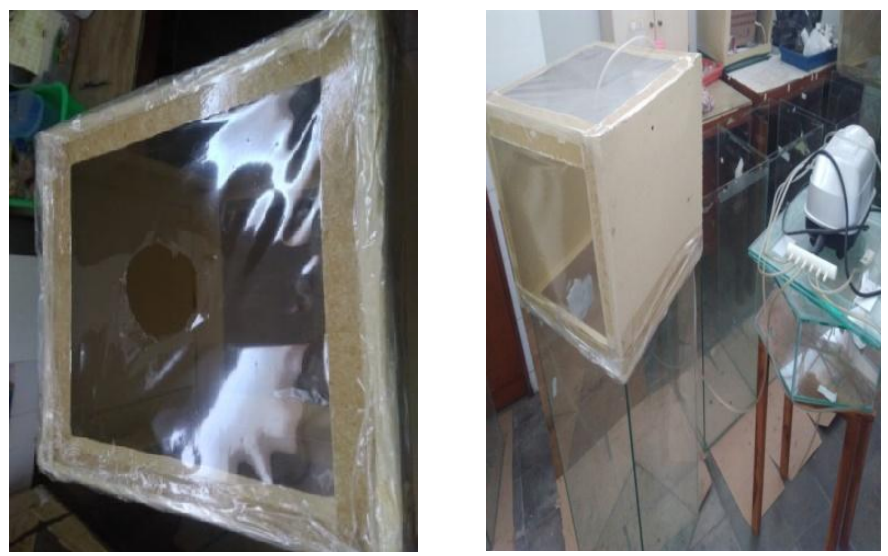

Fig. 3. Detail of the second modified Olfactometer. From left to right - Cage with rice plant, the hole bottom of carboard as glass cover replacement, connection of cage, covers and aerators

$\square$ Methanol extracts $\square$ Chloroform extracts

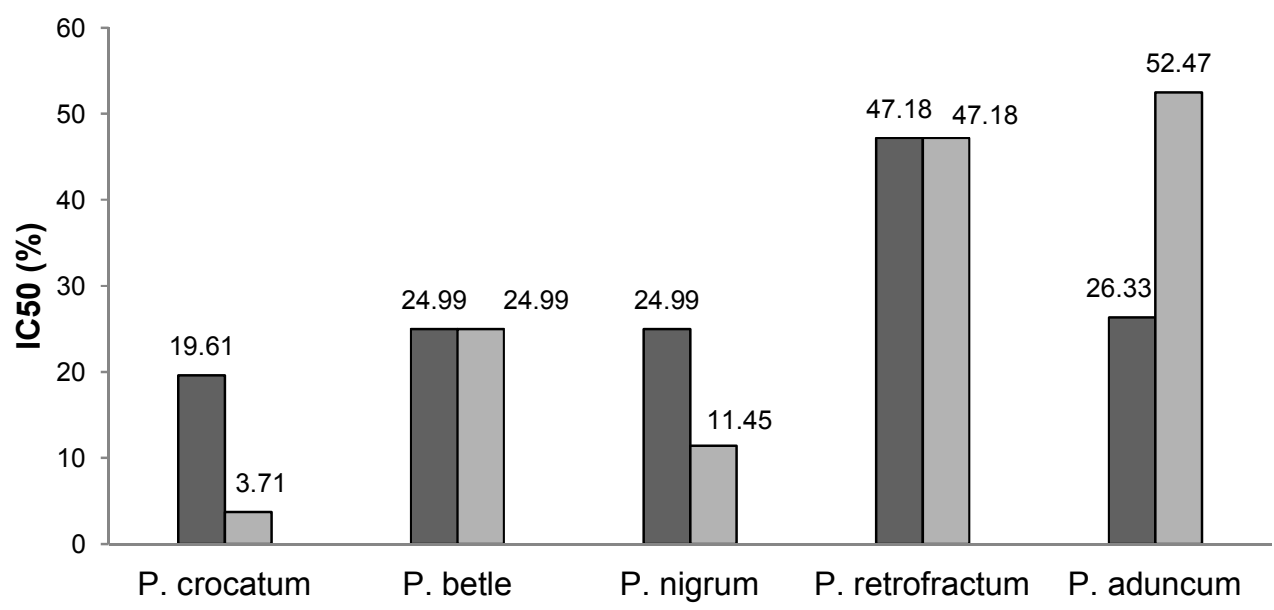

Fig. 4. Repellent activities of chloroform and methanol extract from five species Piper on rice ear bug (Leptocorisa oratorius Fabricius) 
From the Fig. 4, it can be seen that chloroform extract of Piper crocatum was the most potent extract since it had the lowest $I_{50}$. The lower repellent concentration $\mathrm{IC}_{50}$ means the highest repellence activity. The activities of plant extract were depending on the phytochemicals composition of each solution which had active compound chase rice ear bug from the mature milk rice. The most active compounds were normally secondary metabolites. It is known that secondary metabolites are characteristic for each species although known that the production are affected by their environment.

Repellence of rice ear bugs caused by Piper spp. leaves extract was suspected through several ways, namely fumigant and nervous system. Moreover, it can occur as fumigant by the statement of Matsumura [14], respiratory poison is an effect when a compound enters the body of an insect and can interfere with the performance of the respiratory tract. Insecticidal compounds can enter the body of insects in the form of gas through stigma or spiracles that are in the respiratory tract and into the trachea and finally can enter the tissue.

Piper spp. compounds, especially from $P$. crocatum extract, is quickly evaporates and captured by the olfactory receptor neurons in the sense of smell and antenna of rice ear bugs. This will affect nerves function by inhibiting the performance of the enzyme acetylcholinesterase. When the performance of the acetylcholinesterase enzyme is inhibited, the hydrolysis of acetylcholine becomes disrupted, so that the accumulation of acetylcholine increases and causes the muscle performance to continue to be active, quickly tense, and it can cause paralysis and even death effects on insects $[15,16]$. Non-polar compounds are also found in Piper spp. extracts, such as alkaloids and terpenoids. In addition, the compounds in Piper spp. leaves extract can be antifeedant, when the extract in high concentration, insects will not eat the grains of rice affected by the extract. This can cause a lack of food intake and energy production in the stink bugs, so the stink bugs will move, and even lead to death [17].

\subsection{Volatile Compounds of Piper spp.}

Based on mass spectra of gas chromatograms followed by identification of the spectra based on the similarity with Wiley7Nist05.L data based, it were known that there were high variation of secondary metabolites. Total number of compounds found in five leaves extracts of Piper spp. were 88 compounds. $P$. crocatum and $P$. longum leaves extracts contained the highest number of compounds (71 kind of compounds) followed by $P$. nigrum, $P$. betle, and $P$. aduncum leaves extracts with the number of compounds were 45, 42, 37 compounds respectively (Table 1).

\subsection{Specific Compounds of $P$. crocatum Chloroform Leaves Extract}

Concerning the repellent activities results, it found that highest repellent activities was chloroform extract of $P$. crocatum. The number of specific compounds in $P$. crocatum played an important role in the repellent activities considering that chloroform extract of $P$. longum had the same number of compounds. Therefore, the analysis was continued to identify a specific compound in the chloroform extract of $P$. crocatum which were not found in other extracts using GC-MS. The compounds were showed in Table 2. The example of GC-MS chromatogram from the chloroform leaves extract of $P$. crocatum could be seen in Fig. 5.

From data in Table 2, it was known that there were 28 compounds in the chloroform extract of Piper crocatum, which were not found in other extracts. The compounds consists of terpenes, monoterpenes, sesquiterpense, hydrocarbons, and fatty groups. Myrcene (monoterpene) was found to be the highest content. Based on literature studies it is known that some of them were known had repellent activities. The description is displayed in Table 3. From the literature studies, it is known that some of the specific compounds found in chloroform extract of $P$. crocatum showed repellent and toxic activities. Therefore, it was the reason why chloroform extract of $P$. crocatum played an important role in rice ear bug repellent.

\subsection{Terpenes as a Chemical Defense}

Terpenes are the largest group of natural products from plants comprising essential oils, flavours, fragrances, and lipid-soluble plant pigments. These hydrophobic compounds are usually stored in plants in resin ducts, oil cells or glandular trichomes. They are derived from 5carbon isoprene units, such as $\mathrm{C}_{5}$ hemiterpenes, $\mathrm{C}_{10}$ monoterpenes, $\mathrm{C}_{15}$ sesquiterpenes, $\mathrm{C}_{20}$ diterpenes, $\mathrm{C}_{25}$ sesterpenes, $\mathrm{C}_{30}$ triterpenes, $\mathrm{C}_{40}$ tetraterpenes, and $\mathrm{C}_{50}$ band over polyterpenes [33]. 
The mixtures of terpenes containing compounds with different physical properties may be more toxic with longer persistence of defenses. Terpenes synergize the effects of other toxins by acting as solvents to facilitate their passage through membranes. An example of such synergism seems to occur in conifer resin, which is a mixture of monoterpene olefins with antiherbivore and anti-pathogen activity, and diterpenes that are toxic and deterrent to herbivores [16].

Table 1. Volatile compounds of five Piper spp. chloroform leaves extract

\begin{tabular}{|c|c|c|c|c|c|c|}
\hline No. & Compound names & $\begin{array}{l}P . \\
\text { aduncum }\end{array}$ & $\begin{array}{l}P . \\
\text { betle }\end{array}$ & $\begin{array}{l}P . \\
\text { crocatum }\end{array}$ & $\begin{array}{l}P . \\
\text { longum }\end{array}$ & $\begin{array}{l}P . \\
\text { nigrum }\end{array}$ \\
\hline 1 & 1-Hexadecanol & 0 & 0 & 1 & 1 & 0 \\
\hline 2 & $\begin{array}{l}\text { 2-Hexadecen-1-ol, 3,7,11,15- } \\
\text { tetramethyl- }\end{array}$ & 1 & 0 & 0 & 0 & 0 \\
\hline 3 & $\begin{array}{l}9,12-\text { Hexadecadienoic acid, methyl } \\
\text { ester }\end{array}$ & 0 & 0 & 0 & 0 & 1 \\
\hline 4 & 9,12-Octadecadienoic acid & 1 & 0 & 0 & 0 & 1 \\
\hline 5 & 9-Eicosyne & 1 & 1 & 0 & 0 & 0 \\
\hline 6 & $\begin{array}{l}\text { Benzenepropanoic acid, methyl } \\
\text { ester }\end{array}$ & 0 & 0 & 0 & 1 & 0 \\
\hline 7 & Benzylmalonic acid & 0 & 0 & 0 & 1 & 0 \\
\hline 8 & $\begin{array}{l}\text { Cholest-5-en-3-ol (3.beta.)-, } \\
\text { tetradecanoate }\end{array}$ & 1 & 1 & 0 & 0 & 0 \\
\hline 9 & $\begin{array}{l}\text { Cyclohexane, 2-chloro-4-methyl-1- } \\
\text { (1-methylethyl)- }\end{array}$ & 1 & 0 & 0 & 0 & 0 \\
\hline 10 & Cyclohexane, eicosyl- & 1 & 0 & 1 & 0 & 0 \\
\hline 11 & Ergost-5-en-3-ol, (3.beta.)- & 1 & 1 & 0 & 0 & 1 \\
\hline 12 & Eugenol & 1 & 1 & 0 & 0 & 0 \\
\hline 13 & Hexadecanoic acid & 1 & 1 & 0 & 1 & 1 \\
\hline 14 & Hexadecanoic acid, methyl ester & 1 & 1 & 1 & 1 & 0 \\
\hline 15 & Hinokinin & 0 & 0 & 0 & 0 & 1 \\
\hline 16 & Neophytadiene & 1 & 0 & 1 & 1 & 0 \\
\hline 17 & Octadecanoic acid & 1 & 1 & 1 & 1 & 0 \\
\hline 18 & $\begin{array}{l}\text { Octadecanoic acid, 10-oxo-, } \\
\text { methyl ester }\end{array}$ & 1 & 0 & 0 & 0 & 0 \\
\hline 19 & Octadecanoic acid, methyl ester & 1 & 0 & 1 & 0 & 0 \\
\hline 20 & Phytol & 0 & 1 & 1 & 1 & 1 \\
\hline 21 & Piperine & 0 & 0 & 0 & 1 & 1 \\
\hline 22 & Stigmast-4-en-3-one & 1 & 0 & 1 & 0 & 0 \\
\hline 23 & Stigmast-5-en-3-ol, (3.beta.,24S)- & 0 & 0 & 0 & 1 & 1 \\
\hline 24 & $\begin{array}{l}\text { Stigmasta-5,22-dien-3-ol, acetate, } \\
\text { (3.beta.,22Z)- }\end{array}$ & 1 & 1 & 0 & 0 & 0 \\
\hline 25 & Stigmasterol & 0 & 1 & 1 & 1 & 1 \\
\hline 26 & Tridecanol & 1 & 0 & 0 & 0 & 0 \\
\hline 27 & Vitamin $\mathrm{E}$ & 0 & 1 & 1 & 1 & 1 \\
\hline 28 & Eugenyl acetate & 0 & 1 & 0 & 0 & 0 \\
\hline 29 & Globulol & 0 & 1 & 0 & 0 & 0 \\
\hline 30 & Octadecanal & 0 & 1 & 0 & 0 & 0 \\
\hline 31 & $\begin{array}{l}\text { 9,12-Octadecadienoic acid, methyl } \\
\text { ester }\end{array}$ & 0 & 1 & 1 & 0 & 0 \\
\hline 32 & Tetrahydroionone & 0 & 1 & 0 & 0 & 0 \\
\hline 33 & Dioctyl phthalate & 0 & 1 & 1 & 1 & 1 \\
\hline 34 & 2-Palmityl-1,3-diacetin & 0 & 1 & 0 & 0 & 0 \\
\hline 35 & 2-Linolenyl-1,3-diacetin & 0 & 1 & 0 & 0 & 0 \\
\hline 36 & Isomyrcenylacetate & 0 & 1 & 0 & 0 & 0 \\
\hline 37 & Dicholesteryl succinate & 0 & 1 & 1 & 0 & 1 \\
\hline 38 & Epiaplysterylacetate & 0 & 1 & 0 & 0 & 0 \\
\hline
\end{tabular}




\begin{tabular}{|c|c|c|c|c|c|c|}
\hline No. & Compound names & $\begin{array}{l}P . \\
\text { aduncum }\end{array}$ & $\begin{array}{l}P . \\
\text { betle }\end{array}$ & $\begin{array}{l}\text { crocatum } \\
\text { croctu }\end{array}$ & $\begin{array}{l}P . \\
\text { longum }\end{array}$ & $\begin{array}{l}P . \\
\text { nigrum }\end{array}$ \\
\hline 39 & Chavicol & 0 & 1 & 0 & 0 & 0 \\
\hline 40 & Kauren-18-ol, acetate, (4.beta.)- & 0 & 1 & 0 & 0 & 0 \\
\hline 41 & 5.alpha.-Ergost-8(14)-ene & 0 & 1 & 0 & 0 & 0 \\
\hline 42 & Myrcene & 0 & 0 & 1 & 0 & 0 \\
\hline 43 & Limonene & 0 & 0 & 1 & 0 & 0 \\
\hline 44 & Ocimene & 0 & 0 & 1 & 0 & 0 \\
\hline 45 & Terpinolene & 0 & 0 & 1 & 0 & 0 \\
\hline 46 & Myrcenol & 0 & 0 & 1 & 0 & 0 \\
\hline 47 & Geraniol & 0 & 0 & 1 & 0 & 0 \\
\hline 48 & 4-Tolualdehyde & 0 & 0 & 1 & 0 & 0 \\
\hline 49 & 1,6-Octadiene, 3,5-dimethyl- & 0 & 0 & 1 & 0 & 0 \\
\hline 50 & Caryophyllene & 0 & 0 & 1 & 1 & 0 \\
\hline 51 & Bergamotene & 0 & 0 & 1 & 0 & 0 \\
\hline 52 & Gamma-Cadinene & 0 & 0 & 1 & 0 & 0 \\
\hline 53 & Ledol & 0 & 0 & 1 & 0 & 0 \\
\hline 54 & Bisabolol & 0 & 0 & 1 & 0 & 0 \\
\hline 55 & 1-Octadecyne & 0 & 0 & 1 & 1 & 1 \\
\hline 56 & 3-Octadecyne & 0 & 0 & 1 & 0 & 0 \\
\hline 57 & Trans-Stigmasta-5,22-dien-3.bet-ol & 0 & 0 & 1 & 0 & 0 \\
\hline 58 & 4,22-Cholestadien-3-one & 0 & 0 & 1 & 0 & 0 \\
\hline 59 & $\begin{array}{l}\text { Pentalene, octahydro-1-(2- } \\
\text { octyldecyl) }\end{array}$ & 0 & 0 & 1 & 0 & 0 \\
\hline 60 & Sabinene & 0 & 0 & 1 & 0 & 0 \\
\hline 61 & Terpilene & 0 & 0 & 1 & 0 & 0 \\
\hline 62 & Crithmene & 0 & 0 & 1 & 0 & 0 \\
\hline 63 & Linalool & 0 & 0 & 1 & 0 & 0 \\
\hline 64 & beta.-Elemene & 0 & 0 & 1 & 0 & 0 \\
\hline 65 & Zingiberene & 0 & 0 & 1 & 0 & 0 \\
\hline 66 & beta.-Selinene & 0 & 0 & 1 & 0 & 0 \\
\hline 67 & Gamma-Cadinene & 0 & 0 & 1 & 0 & 0 \\
\hline 68 & Alpha.-Copaene & 0 & 0 & 1 & 0 & 0 \\
\hline 69 & Gamma.-Gurjunene & 0 & 0 & 1 & 0 & 0 \\
\hline 70 & Nerolidol & 0 & 0 & 1 & 0 & 0 \\
\hline 71 & Caryophyllene oxide & 0 & 0 & 1 & 1 & 0 \\
\hline 72 & Farnesene & 0 & 0 & 1 & 0 & 0 \\
\hline 73 & 6-Octadecenoic acid, methyl ester & 0 & 0 & 1 & 0 & 0 \\
\hline 74 & 1-Eicosanol & 0 & 0 & 1 & 0 & 1 \\
\hline 75 & 5-Octadecenoic acid, methyl ester & 0 & 0 & 0 & 1 & 0 \\
\hline 76 & $\begin{array}{l}\text { 11,14-Eicosadienoic acid, methyl } \\
\text { ester }\end{array}$ & 0 & 0 & 0 & 1 & 0 \\
\hline 77 & 2-Decenylsuccinic anhydride & 0 & 0 & 0 & 1 & 0 \\
\hline 78 & 1-Undecyne & 0 & 0 & 0 & 1 & 0 \\
\hline 79 & Germacrene d & 0 & 0 & 0 & 1 & 0 \\
\hline 80 & 1-Decene, 8-methyl- & 0 & 0 & 0 & 1 & 0 \\
\hline 81 & 9-Octadecen-1-ol & 0 & 0 & 0 & 1 & 0 \\
\hline 82 & $9,12,15$-Octadecatrienal & 0 & 0 & 0 & 1 & 1 \\
\hline 83 & Oxirane, dodecyl & 0 & 0 & 0 & 1 & 0 \\
\hline 84 & $\begin{array}{l}\text { Cyclohexane, (2-ethyl-1-methyl-1- } \\
\text { butenyl)- }\end{array}$ & 0 & 0 & 0 & 0 & 1 \\
\hline 85 & Alloaromadendrene & 0 & 0 & 0 & 0 & 1 \\
\hline 86 & Patchulane & 0 & 0 & 0 & 0 & 1 \\
\hline 87 & 3,4-(Methylenedioxy)toluene & 0 & 0 & 0 & 0 & 1 \\
\hline 88 & Gamma.-Tocopherol & 0 & 0 & 0 & 0 & 1 \\
\hline Total & number of compounds & 37 & 42 & 71 & 71 & 45 \\
\hline
\end{tabular}

Note: 0: absent, 1: presence 


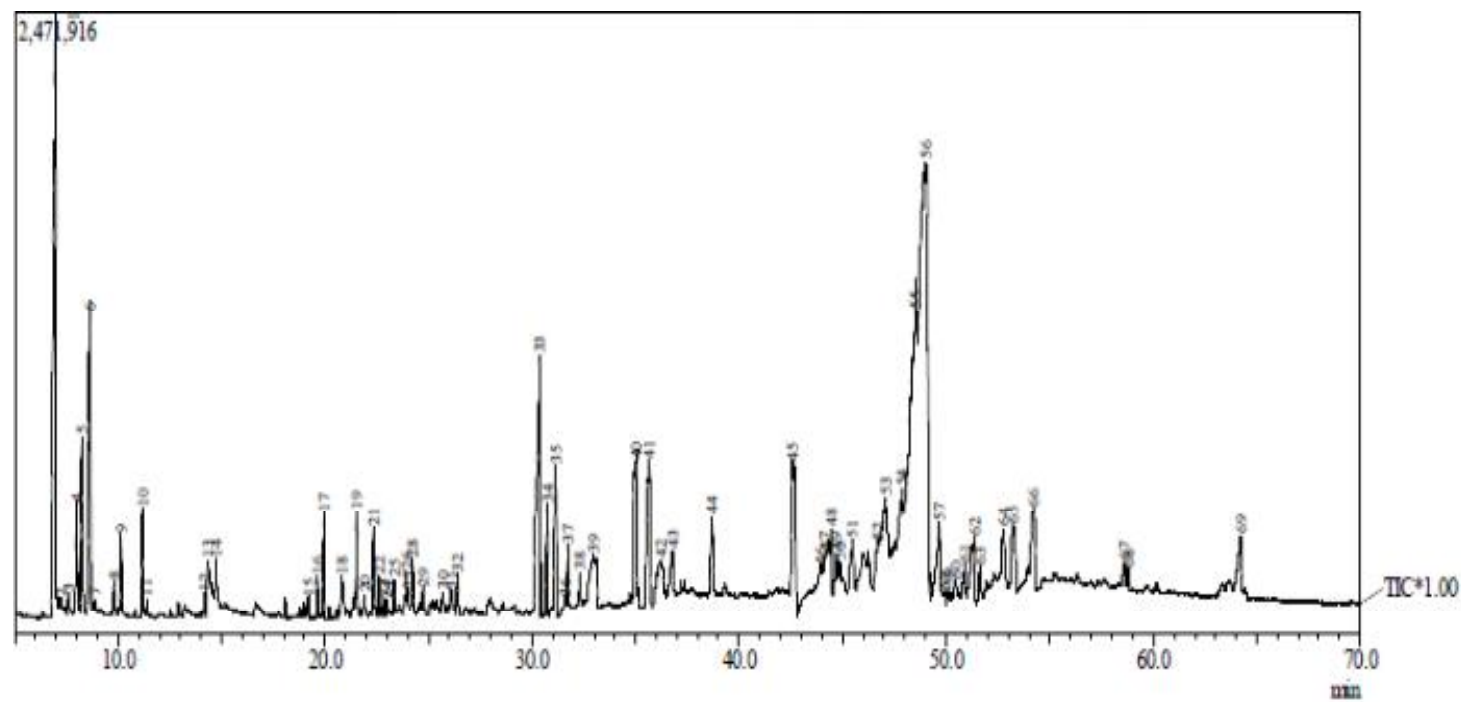

Fig. 5. GC-MS chromatograms of $P$. crocatum chloroform leaves extract

Table 2. Specific compound in the leave of $P$. crocatum which were not found in other four Piper spp. detected from GC-MS chromatograms

\begin{tabular}{lllll}
\hline No. & Compounds & Groups & Retention time (minute) & \% Area \\
\hline 1 & Sabinene & Monoterpene & 7.258 & 0.26 \\
2 & Terpilene & Monoterpene & 7.622 & 0.31 \\
3 & Crithmene & Monoterpene & 8.892 & 0.1 \\
4 & Myrcene & Monoterpene & 6.984 & 8.6 \\
5 & Limonene & Monoterpene & 8.006 & 1.06 \\
6 & Ocimene & Monoterpene & 8.654 & 1.56 \\
7 & Terpinolene & Terpene & 9.817 & 0.22 \\
8 & Linalool & Monoterpene & 10.147 & 0.62 \\
9 & Myrcenol & Monoterpene & 11.375 & 0.17 \\
10 & Geraniol & Monoterpene & 14.164 & 0.17 \\
11 & 4-Tolualdehyde & Aldehyde & 14.353 & 1.14 \\
12 & 1,6-Octadiene, 3,5-dimethyl- & Hydrocarbon & 14.732 & 0.53 \\
13 & Beta.-Elemene & Sesquiterpene & 19.188 & 0.16 \\
14 & Zingiberene & Sesquiterpene & 19.642 & 0.26 \\
15 & Beta.-Selinene & Sesquiterpene & 20.81 & 0.49 \\
16 & Bergamotene & Sesquiterpene & 22.343 & 0.84 \\
17 & Gamma-Cadinene & Sesquiterpene & 22.597 & 0.37 \\
18 & Alpha.-Copaene & Sesquiterpene & 22.825 & 0.11 \\
19 & Gamma.-Gurjunene & Sesquiterpene & 22.975 & 0.1 \\
20 & Nerolidol & Sesquiterpene & 23.342 & 0.3 \\
21 & Caryophyllene oxide & Sesquiterpene & 23.937 & 0.43 \\
23 & Farnesene & Sesquiterpene & 24.042 & 0.18 \\
24 & Ledol & Sesquiterpene & 25.656 & 0.66 \\
25 & Bisabolol & Sesquiterpene & 26.374 & 0.28 \\
26 & 3-Octadecyne & Hydrocarbon & 31.016 & 0.79 \\
27 & 6-Octadecenoic acid, methyl & Fatty acid & 31.575 & 0.15 \\
& ester & & 0.83 \\
28 & 1-Eicosanol & Fatty alcohol & 38.674 & \\
\hline
\end{tabular}


Table 3. Essential oil of $P$. crocatum chloroform leaves extract with insecticidal potency

\begin{tabular}{|c|c|c|c|c|c|}
\hline No. & Compounds & Groups & Biological properties & Target insects & References \\
\hline 1 & Myrcene & Monoterpene & Repellent activity & Tribolium castaneum Herbst & [18] \\
\hline 2 & Limonene & Monoterpene & Repellent activity & Tribolium castaneum Herbst & {$[18,19]$} \\
\hline 3 & Ocimene & Monoterpene & Repellent activity & Anopheles arabiensis, Aedes aegypti & [20] \\
\hline 4 & Terpinolene & Terpene & Fumigant, Repellent activity & $\begin{array}{l}\text { Tribolium castaneum, Liposcelis } \\
\text { bostrychophila }\end{array}$ & [21] \\
\hline 5 & Geraniol & Monoterpene & Repellent activity, antifeedant effect & $\begin{array}{l}\text { Tyrophagus putrescentiae, Otodectes } \\
\text { cynotis, Periplaneta americana, Blaberus } \\
\text { discoidalis }\end{array}$ & [19] \\
\hline 6 & Bergamotene & Sesquiterpene & Systemic defense from herbivory & Manduca sexta & [22] \\
\hline 7 & Ledol & Sesquiterpene & Aphidicidal activities & $\begin{array}{l}\text { Aphis gossypii Glover, Aphis spiraecola } \\
\text { Patch, Myzus persicae (Sulzer) }\end{array}$ & [23] \\
\hline 8 & Bisabolol & Sesquiterpene & Insecticidal activity, larvacidal & Bemisia argentifolii, Aedes aegypti & {$[24,25]$} \\
\hline 9 & Sabinene & Monoterpene & Repellent activity & Bemisia tabaci & [26] \\
\hline 10 & Linalool & Monoterpene & Repellent activity & $\begin{array}{l}\text { Tribolium castaneum, Lasioderma } \\
\text { serricorne, Liposcelis bostrychophila }\end{array}$ & {$[27]$} \\
\hline 11 & Beta elemene & Sesquiterpene & Repellent activity & Bemisia tabaci & [26] \\
\hline 12 & Gamma cadinene & Sesquiterpene & Insectisidal, Repellent activity & Sitotroga cerealella & [28] \\
\hline 13 & Caryophyllene oxide & Sesquiterpene & Toxic effects, repellency and respiration rate & Sitophilus granarius L. & [29] \\
\hline 14 & Zingiberene & Sesquiterpene & Repellent activity & Tribolium castaneum & [30] \\
\hline 15 & Farnesene & Sesquiterpene & Repellent pheromone & Myzus persicae & [31] \\
\hline 16 & 1-Eicosanol & Fatty alcohol & Attractiveness, Repellent activity & Apis andreniformis, Apis florea & [32] \\
\hline
\end{tabular}


Tholl [34] said that terpenes are produced by plants to control pests and as abiotic stress defense. In this study, compounds from the terpene, monoterpene and sesquiterpene groups were found in the leaves of Piper spp., especially in $P$. crocatum. This further reinforces that the terpene group has the potential as a biopesticide to repel rice ear bugs.

\section{CONCLUSION}

Chloroform leaves extract of $P$. crocatum was the most potent material as the repellent of rice ear bug than those of four others. Based on GC-MS studies, the extract had 28 specific compounds which were not found in the other species. Literature studies showed that most of the compounds had repellant activities from monoterpene and sesquiterpene groups.

\section{ACKNOWLEDGEMENTS}

The authors express many thanks to Government of Republic Indonesia for the research financial under the Basic Research Grand 2019 scheme and Universitas Gadjah Mada, Indonesia for the financial and publication support under the Thesis Recognition Program (RTA 2020) Scheme.

\section{COMPETING INTERESTS}

Authors have declared that no competing interests exist.

\section{REFERENCES}

1. Nofiardi E, Sarbino, Rianto, Fadjar. Fluktuasi populasi dan keparahan serangan walang sangit (Leptocorisa oratorius F.) pada tanaman padi di desa sejiram kecamatan tebas kabupaten sambas. Jurnal Sains Mahasiswa Pertanian. 2016;5(2). Indonesia

2. Haladestra E, Djamilah, Nadrawati. Insidensi semusim walang sangit Leptocorisa acuta Thunberg pada padi sawah di Dusun Besar. ThesisUniversitas Bengkulu. Indonesia; 2013.

3. Leatemia JA, Rumthe RY. Studi Kerusakan Akibat Serangan Hama pada Tanaman Pangan di Kecamatan Bula, Kabupaten Seram Bagian Timur, Propinsi Maluku. Jurnal Agroforestri. 2011;6(1):5256. Indonesia

4. Leiss KA, Choi $\mathrm{YH}$, Verpoorte $\mathrm{R}$, Klinkhamer P. An overview of NMR-based metabolomics to identify secondary plant compounds involved in host plant resistance. Phytochem. Rev. 2011;10(2): 205-216.

5. Mayanti T, Tjokronegoro R, Supratman U, Mukhtar MR, Awang K, Hadi AHA. Antifeedant triterpenoids from the seeds and bark of Lansium domesticum cV Kokossan (Meliaceae). Molecules. 2011; 16(4):2785-95.

6. Thamrin M, Asikin S, Willis M. Tumbuhan kirinyu Chromolaena odorata (L) (Asteraceae: Asterales) sebagai insektisida nabati untuk mengendalikan ulat grayak Spodoptera litura. Litbang Pert. 2013;32(3):112-121. Indonesia

7. Yunianti L. Uji efektivitas ekstrak daun sirih hijau (Piper betle) sebagai insektisida alami terhadap mortalitas walang sangit (Leptocorisa oratorius). Skripsi. Universitas Sanata Dharma. Indonesia; 2016.

8. Jayalakshmi B, Raveesha KA, Murali M, Amruthesh KN. Phytochemical, antibacterial, and antioxidant studies on leaf extracts of Piper betle. Int. J. Pharm. 2015;7(10).

9. Lister NE, Viany RD, Nasution AN, Zein Rhamiana, Manjang, Yunazar, Munaf, Edison. Antimicrobial activities of methanol extract of sirih merah (Piper crocatum L.) Leaf. J. Chem. Pharm. 2014;6(12):650654.

10. Netto, Elisio Da Costa. Ekstrak Umbi Gadung, Dioscorea hispida Dennst Aksesi Timor Leste sebagai Zat Anti Makan terhadap Walang Sangit, Leptocorisa oratorius Fabricus (Hemiptera: Alydidae), Hama pada Tanaman Padi, Oryza sativa L. Tesis. Universitas Gadjah Mada. Indonesia; 2013.

11. Karsidi J, Rustam $\mathrm{R}$, Laoh JH. Uji beberapa konsentrasi Piper aduncum L. ekstrak daun untuk kontrol Leptocorisa oratorius Fabricius (Hemiptera, Alydidae) tanaman padi (Oryza sativa L.). Jurnal Online Mahasiswa Fakultas Pertanian Universitas Riau. 2014;1(1). Indonesia

12. Adibah A, Dharmana E. Uji efektivitas larvisida rebusan daun sirih (Piper Betle L.) terhadap larva Aedes aegypti: Studi pada nilai LC50, LT50, serta kecepatan kematian larva. JKD. 2017;6(2):244-252. Indonesia

13. Gour S, Tembhre M. Determination of IC50 of Acephate for acetylcholinesterase in various tissues of chick. Asian J. Exp. Sci. 2018;32(2):39-42. 
14. Matsuura H, Fett-Neto AG. Plant alkaloids: Main features, toxicity, and mechanisms of action. Plant Toxins. 2015;1-5.

15. Khaleel C, Tabanca N, Buchbauer G. $\alpha-$ Terpineol, a natural monoterpene: A review of its biological properties. Open Chem. 2018;16:349-361.

16. Rhattan Rattan RS. Mechanism of action of insecticidal secondary metabolites of plant origin. J. Crop Prot. 2010;29:913920.

17. Kurniawan Kurniawan N, Yuliani, Rachmadiarti F. Bioaktivitas ekstrak daun suren (Toona sinensis) terhadap mortalitas larva Plutella xylastella pada tanaman sawi hijau (Brassica rapa). LenteraBio. 2013; 2(3):203-206. Indonesia

18. Caballero-Gallardo K, Olivero-Verbel J, Stashenko EE. Repellent activity of essential oils and some of their individual constituents against Tribolium castaneum herbst. J Agric Food Chem. 2011;59(5): 1690-1696.

19. Liang JY, Guo SS, Zhang WJ, Geng ZF, Deng ZW, Du SS, Zhang J. Fumigant and repellent activities of essential oil extracted from Artemisia dubia and its main compounds against two stored product pests. Nat. Prod. Res. 2018;32(10):12341238.

20. Dube FF, Tadesse $\mathrm{K}$, Birgersson $\mathrm{G}$, Seyoum E, Tekie H, Ignell R, Hill SR. Fresh, dried or smoked? Repellent properties of volatiles emitted from ethnomedicinal plant leaves against malaria and yellow fever vectors in Ethiopia. Malar J. 2011;10:375.

21. Chen W, Viljoen AM. Geraniol-A rebiew of a commercially important fragrance material. S. Af. J. Bot. 2010;76:643651.

22. Zhou W, Kugler A, McGale E, Kessler D, Baldwin IT, Xu S. Tissue-specific emission of $(E)$-a-bergamotene helpps resolve the dilemma when pollinators are also herbivores. Current Biology. 2017;27: 1336-1341.

23. Albouchi F, Ghazouani N, Abdettabba M, Boukhris-Boauhachem S. Aphidicidal activities of Melaleuca styphenioides Sm. Essential oils on three citrus aphids: Aphis gossypii Glover, Aphis spiraecola Patch and Myzus persicae (Sulzer). S. Afr. J. Bot. 2018;117:149-154.

24. Kamatou GPP, Viljoen A. A review of the application and pharmacological properties of $\alpha$-bisabolol and $\alpha$-bisabolol-rich oils. J. Am. Oil Chem. Soc. 2009;87(1):1-7.

25. Furtado RF, De Lima MGA, Neto MA, Bezerra JNS, Silva EMG. Atividade larvicida de leos essenciais Contra Aedes aegypti L. (Diptera: Culicidae). Neotrop. Entomol. 2005;34:843-847.

26. Costa ECC, Christofoli M, de SouzaCosta GC, Peixoto MF, Fernandes JB, Forim MR, Pereira KC, Silva FG, Cazal CM. Essential oil repellent action of plants of the genus Zanthoxylum against Bemisia tabaci biotype B (Homoptera: Aleyrodidae). Sci Hortic. 2017;226:327332.

27. Cao J, Guo S, Wang Y, Pang X, Geng Z, Du $S$. Toxicity and repellency of essential oil from Evodia lenticellata Huang fruits and its major monoterpenes against three stored product insects. Ecotoxicol. Environ. Saf. 2018;160:342-346.

28. Adjalian E, Sessou P, Odjo T, Figueredo G, Kossou D, Avlessi F, Menut C, Sohounhloué D. Chemical composition and insecticidal and repellent effect of essential oils of two Premna Species against Siitotroga cerealella. Journal of Insects. 2015;2015:1-6.

29. Plata-Rueda A, Campos JM, Rolim GS, Martinez LC, Santos MHD, Fernandes FL, Serrao JE, Zanuncio JC. Terpenoid constituents of cinnamon and clove essential oils cause toxic and behavior repellency response on granary weevil, Sitophilus grnarius. Ecotoxicol. Environ. Saf. 2018;156:263-270.

30. You CX, Zhang WJ, Guo SS, Wang CF, Yang K, Liang JY, Wang Y, Geng Z, Du SS, Deng Z. Chemical composition of essential oils extracted from six Murraya species and their repellent activity against Tribolium castaneum. Ind. Crops Prod. 2015;76:681-687.

31. Bhatia V, Maisnam J, Jain A, Sharma KK, Bhattacharya R. Aphid-repellent pheromone E-b-farnesene is generated in transgenic Arabidopsis thaliana overexpressing farnesyl diphosphate synthase2. Ann. Bot. 2015;115:581-591.

32. Suwannapong G, Benbow ME, Chinokul C, Venkataramegowda S. Bioassay of the mandibular gland pheromones of Apis florea on foreign activity of dwarf honey bees. J. Apic. Res. 2011;50(3):212-217.

33. Wink M, Schimmer O. Modes of action of defensive secondary metabolites. In: Wink, 
M. (Ed.), Functions of plant secondary metabolites and their exploitation in biotechnology. Annual Plant Reviews No. 3. Sheffield Academic Press, Sheffield. 1999;17e133.
34. Tholl D. Biosynthesis and biological functions of terpenoids in plants. Biotechnology of Isoprenoids. 2015;63106.

(c) 2020 Nugroho et al.; This is an Open Access article distributed under the terms of the Creative Commons Attribution License (http://creativecommons.org/licenses/by/4.0), which permits unrestricted use, distribution, and reproduction in any medium, provided the original work is properly cited.

Peer-review history:

The peer review history for this paper can be accessed here:

http://www.sdiarticle4.com/review-history/60165 